\title{
Assessment of the Risk of Colorectal Cancer in Patients with Diabetes Mellitus
}

\author{
Alexandra Agache ${ }^{1,2}$, Andra Bîrligea', Sabin Botea', Mihai Cirstea', Octavian Mihalache' ${ }^{1,2}$, Petronel Mustățea ${ }^{1,2}$ \\ 1"Dr. I. Cantacuzino" Clinical Hospital, Department of General Surgery "I. Juvara", Bucharest, Romania \\ 2"Carol Davila" University of Medicine and Pharmacy, Bucharest, Romania
}

${ }^{*}$ Corresponding author: Andra Bîrligea, MD

"Dr. I. Cantacuzino" Clinical Hospital 5-7 Ion Movila street, sect 2 Bucharest, Romania

E-mail: abirligea@yahoo.com

\section{Rezumat}

Evaluarea riscului de cancer colorectal la pacientii cu diabet zaharat II

Introducere: Incidența crescută atât a cancerului colorectal cât şi a diabetului zaharat de tip II, precum şi faptul că reprezintă cauze importante de morbiditate şi mai ales mortalitate crescute, încadrează cele două patologii pe lista de priorități a sistemului de sanitar. Există studii care au observat că diabetul zaharat este implicat direct în carcinogeneză şi reprezintă un factor de risc independent pentru apariția cancerului colorectal. Pacientul diabetic necesită o abordare medico-chirurgicală complexă, astfel că stabilirea unor criteriilor de risc reprezintă punctul de pornire pentru îmbunătățirea ratei de supraviețuire.

Material şi metodă: Asocierea între cancerul colorectal şi diabetul zaharat tip II precum şi criterii de risc au fost analizate într-un studiu descriptiv prospectiv (442 de pacienti) realizat în Spitalul Clinic Dr I. Cantacuzino în perioada 2017-2018. În cadrul studiului pacienții au fost împărțiți în 2 loturi: 1 lot cu DZ tip II $(\mathrm{N}=194)$ şi 1 lot fără DZ tip II $(\mathrm{N}=248)$ la care s-au efectuat evaluări clinicoparaclinice de bază şi colonoscopii de screening.

Rezultate: S-au evidențiat din punct de vedere statistic $(\mathrm{p}<0,005)$ corelatiii între 7 dintre variabilele testate şi rezultatele pozitive la colonoscopie, ce au fost ulterior combinate pentru realizarea unui scor de risc.

Concluzii: Diabetul zaharat reprezintă un factor de risc independent pentru apariția cancerului colorectal cât şi un factor de prognostic negativ. Scorul de risc descris ca rezultat al acestui studiu reprezintă o soluție fezabilă, simplă pentru depistarea precoce a leziunilor precursoare sau a neoplaziilor cu scopul final de a îmbunătății prognosticul şi supraviețuirea acestor pacienți. 
Cuvinte cheie: cancer colorectal, diabet zaharat, screening

\begin{abstract}
Background:The increased incidence of both colorectal cancer and diabetes mellitus, as well as the fact that they are important causes of high morbidity and especially mortality, place the two pathologies on the list of priorities of the health system. There are studies which have observed that diabetes mellitus is directly involved in carcinogenesis and is an independent risk factor for colorectal cancer. The diabetic patient requires a complex medical-surgical approach, so setting the risk criteria for them can be the starting point for improving the survival rate.

Materials and methods: The association between colorectal cancer and diabetes mellitus as well as screening criteria were analyzed in a descriptive prospective study (442 patients) conducted in the Dr. I. Cantacuzino Clinical Hospital during 2017-2018. In the study, patients were distributed in two clusters, one with diabetes mellitus $(\mathrm{N}=194)$ and one without diabetes mellitus $(\mathrm{N}=248)$ in which basic clinical and laboratory evaluations were performed followed by screening colonoscopies.

Results: Statistically significant $(\mathrm{p}<0.005)$ correlations were highlighted between 7 of the variables tested and the positive results on colonoscopy, which were subsequently combined to achieve a risk score.

Conclusions: Diabetes mellitus is an independent risk factor and a negative prognostic factor for colorectal cancer. The risk score described as a result of this study is a feasible, simple solution for early detection of precursor lesions or neoplasms with the ultimate goal of improving the prognosis and survival of these patient.
\end{abstract}

Key words: colorectal cancer, diabetes mellitus, screening criteria

\section{Background}

Diabetes mellitus is a major reason for concern, in terms of public health with a global prevalence that has increased twice over 34 years $(1980-4.7 \%$ versus $2014-8.5 \%)$ in adults $(1,2)$. The high prevalence (over 13\%) is also maintained for the romanian adult population (20-79 years) and supports the need for action towards this pathology $(3,4)$.

Neoplasia is another pathology of great interest, ranking in second place in terms of overall mortality. In the case of cancer mortality, colorectal neoplasia in Romania $(12.4 \%)$ and also globally $(9.4 \%)$ is on the $2^{\text {nd }}$ place $(5,6)$.

The impact of colorectal cancer screening on the incidence and especially on the mortality rate was major, a fact highlighted and certified by multiple studies (7). The lack of a nationally developed screening program is one of the basic motivations for choosing this topic $(8,9,10)$.

Currently, there is a common point of view among specialists, proving through numerous studies that diabetes mellitus is a risk factor for colorectal neoplasia (11-14), that insulin therapy has a great impact in carcinogenesis and metformin has a protective role (15-18), and that morbidity, the risk of recurrence and mortality are severely altered negatively in this patients (19-22).

The prognosis and survival in colorectal cancer is clearly related to the characteristics of TNM stage classification, hence the importance of detection in the early stages.

In this regard, the aim of the article was to analyze the association between diabetes mellitus as a risk factor for colorectal neoplasms, but especially to establish appropriate risk criteria to increase the rate of cura- 
tive cancer treatments and improve the prognosis and survival rates.

\section{Material and Method}

The study has the following characteristics: unicentric (Clinical Hospital Dr. I. Cantacuzino, Bucharest), descriptive (describes the group of patients in terms of quantified parameters) and correlational (examines the relationship between the parameters analyzed). The study was conducted in accordance with the recommendations of the Hospital Ethics Commission, it included a number of 442 selected patients (meeting the inclusion criteria and the absence of exclusion criteria) presented between January 2017 and December 2018. These patients had no specific digestive symptoms (except abdominal bloating and tendency to constipation) or general symptoms specific to neoplastic diseases, and also with a threshold value of hemoglobin above $10 \mathrm{~g} / \mathrm{dL}$. They were summary evaluated anamnestic, clinical and paraclinical and performed lower digestive endoscopy, after signing an informed consent. Patients were divided into 2 groups: the first group with diabetes mellitus $(\mathrm{N}=194)$ and the second group without diabetes $(\mathrm{N}=248)$ and possible criteria correlated with positive results at colonoscopy (defined as neoplastic precursor lesions or tumors) were analyzed.

The obtained data was introduced in the Microsoft Office Excel 2017 program for basic analysis and statistically processed using Stata 11 and SPSS programs. The distribution of the sample meets the condition of normality, this being proven by the Skewness and Kurtosis test, the values obtained of 0 , confirming the hypothesis of the normality test. We used the Pearson correlation coefficient, Fisher's Exact, chi square test, ods ratio to analyze the level of connection of the variables and we considered an error probability below 0.05 (p) as a statistically significant value.

\section{Results}

We started from a retrospective descriptive study (183 colorectal cancer patients operated in the "I. Juvara" Surgery Department of the "Dr. I. Cantacuzino" Clinical Hospital, between January 2015 and December 2016), where we found that almost a third (31.15\%) associated diabetes. The most common TNM stage at presentation was III (64\%) and the average hospitalization period was 15 days for the group without diabetes and 19 days in the diabetes group. The postoperative complications were also more common in the group with diabetes (wound infection - 18 versus 9 patients, anastomotic fistula $(2.73 \%)-3$ vs. 2 patients) and the survival rate was lower (6 months $84 \%$ vs. $94 \%$, at 24 months $49 \%$ vs. $72 \%)$.

It should be noted from the beginning, that the data in this prospective study revealed a predominance of patients with diabetes compared to positive results on colonoscopy (84 positive results in group 1 vs 55 positive results in group 2 of which 29 patients with tumors in group 1 and 14 patients in group 2). This association was verified and proven statistically significant with a relatively higher risk of 2.7 times for patients with diabetes to develop pathological changes on colonoscopy compared to patients without diabetes. $(\mathrm{p}<0.000, \mathrm{OR}=2.680 ; 95 \% \mathrm{CI}, 1.247$ 4.564).

According to the literature, in our group we also found that there is a statistically significant correlation regarding the gender and the endoscopic positive results in favor of the male patients $(\mathrm{p}<0.037, \mathrm{OR}=1.645$; $95 \%$ CI, $0.427-2.976$ ). The distribution of patients according to age groups shows that the best represented one is the 60-69 years group (group 1 with diabetes $47.94 \%$ vs group $234.67 \%$ ) with a median of 65 years at the level of both groups. Furthermore the groups with positive results have a better heterogenity than that of the group with negative results, with a median value for the first group of 68 years, compared to 64 years at the level of the second group $(\mathrm{p}<0.001)$.

If we take into account BMI values we can sketch the fact that in the group with positive results the median is $28 \mathrm{~kg} / \mathrm{m}^{2}$ (minimum-24 
and maximum- $36.8 \mathrm{~kg} / \mathrm{m}^{2}$ ), while in the group with negative results the median records $27.20 \mathrm{~kg} / \mathrm{m}^{2}$ (minimum-23 and maximum-38 $\mathrm{kg} / \mathrm{m}^{2}$ ). Still, the statistical analysis shows a better heterogenity in the group with positive results, as well as a significant positive correlation $(p<0.000)$.

The analysis of multiple paraclinical criteria outlined two variables which deserve special interest, namely C-reactive protein (CRP) and glycated haemoglobin (HbA1c). CRP calculated values for the whole group compared to the results of the colonoscopy, have a good heterogenity for the group with positive results with a median value of 1.9 $\mathrm{mg} / \mathrm{dL}$ compared to the group with negative results where the median is $0.30 \mathrm{mg} / \mathrm{dL}$. Glycated haemoglobin correlated to the group with positive results has a median value of $8.60 \%$ in the case of the group with tumors, (minimum-7\% and maximum-10.10\%), while in the group with precursor lesions there is a median value of $8 \%$ (minimum-6.8\% and maximum-9.8\%). For both parameters statistically significant associations were highlighted $(\mathrm{p}<0.001)$.

Another variable considered is the impact of antidiabetic treatment on the colonoscopy results. In our study 84 positive results were found, of which 34 were treated with insulin only and 25 with insulin combined regimen. We observed a statistically strong association between the two variables, and a 2.74 times higher risk for patients with insulin treatment of developing colorectal neoplasms than those who do not have insulin in their treatment $(\mathrm{p}<0.000)$.

We also analyzed the correlation between insulin treatment, $\mathrm{HbA1c}$ values and positive results on colonoscopy. We noted the homogenity of the two groups as well as the fact that the median glycated hemoglobin in those with insulin therapy is $8.20 \%$ compared to $7.60 \%$ in those without insulin therapy. There is a positive association between glycated hemoglobin values and insulin treatment for the occurrence of pathological lesions classified as positive results $(\mathrm{p}<0.001)$.
Based on the results presented, we aimed to analyze furthermore these criteria with statistical significance, in terms of a threshold value to detect positive results on colonoscopy so that we can obtain a simple and feasible risk score.

The results of the statistical analysis led to a number of 7 criteria with the following statistically significant threshold values:

- Age $\geq 60$ ani $(\mathrm{p}<0.006, \mathrm{OR}=2.025 ; 95 \%$ CI, 1.223-3.352);

- Gender - Masculine $(\mathrm{p}<0.037$, OR = 1.645; 95\% CI, 0.427-2.976);

- $\mathrm{BMI} \geq 25 \mathrm{~kg} / \mathrm{m}^{2}(\mathrm{p}<0.039$, OR = 1.243; 95\% CI, .562-2.748);

- Onset of diabetes $\geq 5$ years $(\mathrm{p}<0.011$, OR = 3.070; 95\% CI, 1.253-7.523);

- Diabetes treatment Insulin or Insulin combined with oral antidiabetics $(\mathrm{p}<0.000$, $\mathrm{OR}=2.843 ; 95 \%$ CI, 1.958-4.126);

- HbA1c $(\%) \geq 8,5 \%(\mathrm{p}<0.003, \mathrm{OR}=2.735$; 95\% CI, 1.375-5.441);

- $\mathrm{CRP}(\mathrm{mg} / \mathrm{dL}) \geq 2 \mathrm{mg} / \mathrm{dL}(\mathrm{p}<0,000 \mathrm{OR}=$ 13.514; 95\% CI, 7.632-23.931).

The score is presented as a table (Table 1) for which 1 point is awarded if the criteria is met, except for treatment where 1 point is given for combined insulin treatment and 2 points for insulin-only treatment. The maximum value of the score is 8 . For classification into risk groups, the following were highlighted:

- Low risk group - values $\leq 2$;

- Medium risk group - values $\leq 4$

- High risk group - values $\geq 5$.

For the first risk group is recommended to perform noninvasive tests and surveillence, while for the other 2 risk groups we indicate colonoscopic screeening for colorectal cancer.

Table 1. Risk score for colorectal cancer

\begin{tabular}{lll}
\hline Age & $\geq 60$ years & 1 \\
\hline Gender & $\mathrm{M}$ & 1 \\
\hline BMI $\left(\mathrm{kg} / \mathrm{m}^{2}\right)$ & $\geq 25 \mathrm{~kg} / \mathrm{m}^{2}$, & 1 \\
\hline Diabetes onset (years) & $\geq 5$ & 1 \\
\hline Antidiabetic treatment & Insulin combined with 0AD & 1 \\
& Insulin only & 2 \\
\hline HbA1c $(\%)$ & $\geq 8,5 \%$ & 1 \\
\hline CRP value $(\mathrm{mg} / \mathrm{dL})$ & $\geq 2 \mathrm{mg} / \mathrm{dL}$ & 1 \\
\hline Total & & \\
\hline
\end{tabular}




\section{Discussions}

Diabetes mellitus is a major reason for concern, in terms of public health. World Health Organization estimates that there were around 422 million diabetic patients worldwide in 2014 and their number has continuously increased since then (23). In the same time, colorectal cancer is the second most frequent cause of neoplastic death, although most of its pathogenic factors are related to avoidable diet and life-style habits. Meanwhile, its morbidity and mortality can be significantly decreased using screening methods (24).

Both diabetes mellitus and colorectal cancer are multifactorial diseases. Their association has been debated in several scientific papers; the results of most of them supported the hypothesis of a cause-effect relation. One of the involved mechanism is considered to be a high level of insulin-growthfactor (IGF), determined by chronic hyperglicaemia, which could accelerate the transition of adenomas to cancer. Furthermore, the identification of genetic disorders of the IGF pathway could help an accurate assessment of individual risk for colorectal cancer (25). Diabetes mellitus determines alterations of the metabolic chains of carbohydrates and lipids, augmented serum levels of IGF and adipocytokines and chronic inflammation. The result may well consist of disorders of energy pathways, such as AMP activated kinase, which could lead to genetic instability and DNA mismatch repair, with the final result of an oncogenic mutation (26).

The precise mechanisms involved in carcinogenesis are yet to be established; an interesting hypothesis is correlated to the disruption of microorganisms of the large bowel (so-called "gut microbiota"), which maintain local homeostasis by various complex reactions $(27)$.

The outcome and post-operative survival rate in patients with colorectal cancer is significantly associated to an early-stage diagnosis and to screening programs as comprehensive as possible, while extended cost-effectiveness analysis have been performed in order to establish an optimal strategy. An important change consisted in the re-evaluation of the minimum age of the screened patients: the American Cancer Society appreciated it could be justified to start screening from the age of 45 years instead of 50 years (28). Meanwhile, fecal occult blood tests have been widely replaced by fecal immunochemical tests, in order to identify patients at risk, who should be investigated afterwards using colonoscopy (29).

The main problem of screening programs consists of achieving greater benefits at lower costs and therefore the selection of patients is essential.

In our country the implementation of a colorectal cancer national screening program is yet to be achieved. In 2015,24 of the 27 countries of the European Union had already established or were preparing for such programs (30); it is of the utmost importance for us to have one, based on clear and welldefined criteria. Therefore, the objective of our study was to identify risk factors significantly associated to colorectal cancer in diabetic patients. Afterwards we measured their importance, using statistical methods and the result was represented by an risk score, which we think could become an useful method for choosing the most vulnerable patients, in terms of probability of a neoplastic disease.

The diagnosis of malignant tumors in these patients may be difficult and often delayed. Diabetic neuropathy decreases the intensity of visceral pain and is also responsible for slowing down the intestinal physiologic motility; as a result, two of the essential clinical features of colorectal tumoral obstruction may be significantly modified. The patients are usually admitted during advanced stages of neoplastic disease, when complications become obvious and the prognosis is severely affected. The situation may become even worse in synchronous tumors of the gastrointestinal tract, which require large, multivisceral procedures $(21,22,31)$.

The operations performed in patients with diabetes mellitus are often challenging. A 
meta-analysis including 26 articles demonstrated higher levels of post-operative morbidity and mortality after colorectal surgery (31). First of all, the achievement of quasi-normal values of glycaemia is usually not possible. Metabolic disorders are often triggered and worsened by intestinal obstruction, and large variations of serum glucose are difficult to manage. Among them, hypoglycaemia represents a life-threatening risk, which should be recognized and properly treated by clinicians (32). We should be aware that a normal metabolic balance can only be established when all the underlying conditions have been put aside.

Visceral microangiopathy represents the main cause for delayed and defective postoperative healing, and the rate of anastomotic leakage is higher than in non-diabetic population (in which large, nationwide studies still report rates of $4-5 \%$ ) (33). In order to prevent peritonitis, the solutions may well be the performing of a temporary or definitive colostomy or various techniques of protection of the colonic suture [ileostomy, colostomy,(34) transanal tube (35)]. Surgical site infections are also more frequent, as the procedures involve septic organs and the general immunity is severely decreased, as a consequence of both the metabolic and neoplastic disease (36). The infection may be limited to skin or may extend to soft tissue, which is even more difficult to treat (37). Overall, the results of colorectal surgery in diabetic patients have few reasons for optimism, at least in absence of a national screening program and of early stage diagnosis.

\section{Conclusions}

Colorectal neoplasia, as well as diabetes are a major public health problem due to the increasing prevalence, the negative impact they have on life expectancy and quality of life and the socio-economic impact, representing separately major causes of morbidity and mortality, and in association with exponentially increased risks. The colorectal cancer mortality rate has declined progressively in recent decades, due to: intervention on modifiable risk factors, early detection and curative excision of colonic polyps and tumors and more effective surgical and adjuvant treatment.

Starting with the thorough statistical analysis of the data in the present study, gathered in a complex and coherent manner, we were able to achieve a simple, accessible score to assess the risk for colorectal neoplasia in patients with diabetes mellitus composed of seven criteria and their threshold values: sex (male), BMI ( $\geq 25 \mathrm{~kg} / \mathrm{m}^{2}$ ), age (over 60 years), glycated haemoglobin values $(\geq 8,5 \%)$, onset of diabetes mellitus (over 5 years), antidiabetic treatment (insulin only or combined treatment), C-reactive protein values (> $2 \mathrm{mg} / \mathrm{dL})$. The score aims to classify patients according to the values obtained in 3 risk groups each of them with specific recomandations.

The importance of the risk score resides in the fact that early stage disease has the best outcome, taking full advantage of the progresses made in the field of oncologic surgery. Its importance is emphasized in diabetic patients which have an evolutive potential towards complications. The risk score could become useful in every medical center, as it is a simple and feasible tool. It is also an effective method of establishing the starting point for a proper therapeutic management, with the ultimate goal of improving the quality of life and survival rates.

\section{Acknowledgements}

This material is part of the study for the $\mathrm{PhD}$ thesis 'Screening for colorectal cancer in patients with type II diabetes' (coordinator prof. dr. T. Patrascu).

\section{Funding Details}

This research did not receive any specific grant from funding agencies in the public, commercial or not-for-profit sectors.

\section{Conflict of Interest}

All author declare that they have no conflict of interest. 


\section{Ethics Approval}

All procedure followed have been performed in accordance with the ethical standards laid down in the 1964 Declaration of Helsinki and its later amendments.

\section{References}

1. Saeedi P, Petersohn I, Salpea P, Malanda B, Karuranga S, Unwin N, et al. Global and regional diabetes prevalence estimates for 2019 and projections for 2030 and 2045: Results from the International Diabetes Federation Diabetes Atlas, 9th edition. Diabetes Res Clin Pract. 2019;157:107843.

2. Zimmet PZ, Magliano DJ, Herman WH, Shaw JE. Diabetes: a $21^{\text {st }}$ century challenge. Lancet Diabetes Endocrinol. 2014;2(1):56-64.

3. http://fadr.ro/diabetul-in-romania/

4. Firanescu AG, Popa A, Sandu MM, Protasiewicz DC, Popa SG, Mota M. The global prevalence and incidence of diabetes mellitus and pulmonary tuberculosis. Romanian Journal of Diabetes Nutrition and Metabolic Diseases. 2016;23(3):319-326.

5. GLOBOCAN 2020 https://gco.iarc.fr/today/data/factsheets/cancers/10_ 8_9-Colorectum-fact-sheet.pdf

6. Favoriti P, Carbone G, Greco M, Pirozzi F, Pirozzi RE, Corcione F. Worldwide burden of colorectal cancer: a review. Updates Surg. 2016;68(1):7-11.

7. Schreuders EH, Ruco A, Rabeneck L, Schoen RE, Sung JJ, Young GP, et al. Colorectal cancer screening: a global overview of existing programmes. Gut. 2015;64(10):1637-49.

8. Sporea I, Popescu A. No colorectal cancer screening program in Romania Thus, start with opportunistic screening. Rev Med Chir Soc Med Nat lasi. 2014;118(3):598-600

9. https://mfe.gov.ro/au-fost-lansate-ghidurile-beneficiarilor-privind-programele-de-screening-oncologic-si-depistarea-virusului-hepatic-b-si-c/

10. http://www.ms.ro/2016/04/13/primul-plan-national-multianual-integratde-control-al-cancerului-in-romania/

11. Simons CC, Schouten LJ, Godschalk RW, van Engeland M, van den Brand PA, van Schooten FJ, et al. Genetic Variants in the Insulin-like Growth Factor Pathway and Colorectal Cancer Risk in the Netherlands Cohort Study. Sc Rep. 2015:5:14126.

12. Wang JY, Chao TT, Lai CC, Wang CY, Wu VC, Wang SM, et al. Risk of colorectal cancer in type 2 diabetic patients: a population-based cohort study. Jpn J Clin Oncol. 2013;43(3):258-63.

13. Deng L, Gui Z, Zhao L, Wang J, Shen L. Diabetes mellitus and the incidence of colorectal cancer: an updated systematic review and meta-analysis. Dig Dis Sci. 2012;57(6):1576-85

14. de Kort S, Masclee AAM, Sanduleanu S, Weijenberg MP, van Herk-Suke MPP, Oldenhof NJJ, et al. Higher risk of colorectal cancer in patients with newly diagnosed diabetes mellitus before the age of colorectal cancer screening initiation. Sci Rep. 2017;7:46527.

15. Chang YT, Tsai HL, Kung YT, Yeh YS, Huang CW, Ma CJ, et al. DoseDependent Relationship Between Metformin and Colorectal Cancer Occurrence Among Patients with Type 2 Diabetes-A Nationwide Cohort Study. Transl Oncol. 2018;11(2):535-541.

16. Liu F, Yan L, Wang Z, Lu Y, Chu Y, Li X, et al. Metformin therapy and risk of colorectal adenomas and colorectal cancer in type 2 diabetes mellitus patients: A systematic review and meta-analysis. Oncotarget. 2017; 8(9):16017-16026.

17. Liu $Y$, Jin PP, Sun XC, Hu TT. Thiazolidinediones and risk of colorectal cancer in patients with diabetes mellitus: A meta-analysis. Saudi Gastroenterol. 2018;24(2):75-81.

18. $\mathrm{Ng} \mathrm{CW}$, Jiang $\mathrm{AA}$, Toh EMS, $\mathrm{Ng} \mathrm{CH}$, Ong ZH, Peng S, et al. Metformin and colorectal cancer: a systematic review, meta-analysis and meta-regression. Int J Colorectal Dis. 2020:35(8):1501-1512.

19. Fransgaard T, Thygesen LC, Gögenur I. Increased 30-day mortality in patients with diabetes undergoing surgery for colorectal cancer. Colorectal Dis. 2016;18(1):022-9.

20. Zhu B, Wu X, Wu B, Pei D, Zhang L, Wei L. The relationship between diabetes and colorectal cancer prognosis: A meta-analysis based on the cohort studies. PLoS One. 2017;12(4):e0176068.

21. Li J, Liu J, Gao C, Liu F, Zhao H. Increased mortality for colorectal cancer patients with preexisting diabetes mellitus: an updated meta-analysis. Oncotarget. 2017;8(37):62478-62488.

22. Georgescu DE, Patrascu T, Georgescu TF, Tulin A, Mosoia L, Bacalbasa N, Stiru 0, Georgescu MT. Diabetes Mellitus as a Prognostic Factor for Locally Advanced Rectal Cancer. In Vivo. 2021 Jul-Aug;35(4):2495-2501.

23. Lovic D, Piperidou A, Zografou I, Grassos H, Pittaras A, Manolis A. The Growing Epidemic of Diabetes Mellitus. Curr Vasc Pharmacol. 2020;18(2): 104-109.

24. Siegel RL, Miller KD, Goding Sauer A, Fedewa SA, Butterly LF, Anderson JC, et al. Colorectal cancer statistics, 2020. CA Cancer J Clin. 2020:70(3):145-164.

25. de Kort S, Simons CCJM, van den Brandt PA, Janssen-Heijnen MLG, Sanduleanu S, Masclee AAM, Weijenberg MP. Diabetes mellitus, genetic variants in the insulin-like growth factor pathway and colorectal cancer risk. Int J Cancer. 2019;145(7):1774-1781.

26. Yang J, Nishihara R, Zhang X, Ogino S, Qian ZR. Energy sensing pathways: Bridging type 2 diabetes and colorectal cancer? J Diabetes Complications. 2017:31(7):1228-1236

27. Gao R, Gao Z, Huang L, Qin H. Gut microbiota and colorectal cancer. Eur J Clin Microbiol Infect Dis. 2017:36(5):757-769.

28. Ladabaum U, Mannalithara A, Meester RGS, Gupta S, Schoen RE. CostEffectiveness and National Effects of Initiating Colorectal Cancer Screening for Average-Risk Persons at Age 45 Years Instead of 50 Years. Gastroenterology. 2019;157(1):137-148.

29. Sekiguchi M, Igarashi A, Sakamoto T, Saito Y, Esaki M, Matsuda T. Costeffectiveness analysis of colorectal cancer screening using colonoscopy, fecal immunochemical test, and risk score. J Gastroenterol Hepatol. 2020; 35(9):1555-1561

30. Navarro M, Nicolas A, Ferrandez A, Lanas A. Colorectal cancer population screening programs worldwide in 2016: An update. World J Gastroenterol. 2017:23(20):3632-3642

31. Mills KT, Bellows CF, Hoffman AE, Kelly TN, Gagliardi G. Diabetes mellitus and colorectal cancer prognosis: a meta-analysis. Dis Colon Rectum. 2013; 56(11):1304-19.

32. International Hypoglycaemia Study Group. Hypoglycaemia, cardiovascular disease, and mortality in diabetes: epidemiology, pathogenesis, and management. Lancet Diabetes Endocrinol. 2019;7(5):385-396.

33. Sparreboom CL, van Groningen JT, Lingsma HF, Wouters MWJM, Menon $A G$, Kleinrensink GJ, et al. Different Risk Factors for Early and Late Colorectal Anastomotic Leakage in a Nationwide Audit. Dis Colon Rectum. 2018;61(11):1258-1266

34. Gavriilidis P, Azoulay D, Taflampas P. Loop transverse colostomy versus loop ileostomy for defunctioning of colorectal anastomosis: a systematic review, updated conventional meta-analysis, and cumulative meta-analysis. Surg Today. 2019;49(2):108-117.

35. Okuda Y, Shimura T, Kato H, Yamada T, Hirata Y, Natsume M, et al. Pathological impact of transanal colorectal tube for obstructive colorectal cancer. Surg Endosc. 2020;34(9):4011-4018. Epub 2019 0ct 17. Erratum in: Surg Endosc. 2019 Oct 28

36. Martin ET, Kaye KS, Knott C, Nguyen H, Santarossa M, Evans R, et al. Diabetes and Risk of Surgical Site Infection: A Systematic Review and Meta-analysis. Infect Control Hosp Epidemiol. 2016;37(1):88-99. Epub 2015 0ct 27.

37. Kim EJ, Ha KH, Kim DJ, Choi YH. Diabetes and the Risk of Infection: A National Cohort Study. Diabetes Metab J. 2019;43(6):804-814. 